DOI 10.22460/infinity.v7i2.p83-96

\title{
STUDENTS' PERFORMANCE SKILLS IN CREATIVE MATHEMATICAL REASONING
}

\author{
Heris Hendriana ${ }^{1}$, Rully Charitas Indra Prahmana ${ }^{2}$, Wahyu Hidayat ${ }^{3}$ \\ ${ }^{1,3}$ Institut Keguruan dan Ilmu Pendidikan Siliwangi, Jl. Terusan Jenderal Sudirman, Cimahi, Indonesia \\ ${ }^{2}$ Universitas Ahmad Dahlan, Jl. Pramuka Kampus 2 Unit B Kav 5 Pandeyan, Yogyakarta, Indonesia \\ ${ }^{1}$ herishen@ikipsiliwangi.ac.id, ${ }^{2}$ rully.indra@mpmat.uad.ac.id, ${ }^{3}$ wahyu@ ikipsiliwangi.ac.id
}

Received: April 10, 2018; Accepted: June 10, 2018

\begin{abstract}
This study aims to examine mathematics teacher-candidate students' mathematical creative reasoning ability based on the level of Adversity Quotient (AQ). This study uses a mixed method of sequential type by combining quantitative and qualitative methods in order. Population in this study is all students attending the course of Calculus in Mathematics Education of Study Program at STKIP Siliwangi that consist of 270 students divided into six classes. The results are AQ gives effect to the achievement of students' mathematical creative reasoning abilities based on the whole and the type of AQ climber, champer, and quitter. The achievement of students' mathematical creative reasoning abilities and based on AQ, the champer and climber fall into the medium category, while on the quitter type, it falls into the category of low. On the other hands, the achievement of students' mathematical creative reasoning abilities is yet to be achieved well at the indicator of novelty.
\end{abstract}

Keywords: Adversity Quotient, Creative Reasoning.

\begin{abstract}
Abstrak
Penelitian ini bertujuan untuk menelaah kemampuan penalaran kreatif matematis mahasiswa calon guru matematika berdasarkan tingkat Adversity Quotient (AQ). Penelitian ini menggunakan metode kombinasi tipe sequential explanatory dengan menggabungkan metode kuantitatif dan kualitatif secara berurutan. Populasi dalam penelitian ini adalah semua mahasiswa yang mengikuti program Kalkulus di Program Studi Pendidikan Matematika STKIP Siliwangi yang terdiri dari 270 mahasiswa dibagi menjadi enam kelas. Hasil penelitian menunjukkan bahwa AQ memberikan efek pada pencapaian kemampuan penalaran kreatif matematis mahasiswa berdasarkan keseluruhan dan tipe AQ climber, champer, dan quitter. Pencapaian kemampuan penalaran kreatif matematis mahasiswa berdasarkan AQ climber dan champer termasuk ke dalam kategori sedang, sementara pada jenis AQ quitter termasuk ke dalam kategori rendah. Di sisi lain, pencapaian kemampuan penalaran kreatif matematika mahasiswa belum tercapai dengan baik pada indikator kebaruan.
\end{abstract}

Kata Kunci: Adversity Quotient, Penalaran Kreatif.

How to Cite: Hendriana, H., Prahmana, R. C. I., \& Hidayat, W. (2018). Students' Performance Skills in Creative Mathematical Reasoning. Infinity, 7(2), 83-96. doi:10.22460/infinity.v7i2.p83-96. 


\section{INTRODUCTION}

An environment conducive created to learning is essential to learners' academic achievement (Visser, Juan, \& Feza, 2015). Furthermore, the purpose of learning mathematics in Indonesia among others are to train one's understanding in thinking and reasoning and concluding, develop learners' creativity through imagination, intuition, and the inquiry, and develop problem-solving and communication abilities (Prahmana, Kusumah, \& Darhim, 2017; Soedjadi, 2000). On the other hands, numerous researchers have documented stated that the teaching profession has been recognized as key to improving the quality of education worldwide (Acuña Ruz, 2015; Hendriana, Hidayat, \& Ristiana, 2018; Prahmana \& Kusumah, 2016; Prahmana, Kusumah, \& Darhim, 2017; Weybright, Caldwell, Xie, Wegner, \& Smith, 2017; Young, 2017). School dropout is a crisis whereby Grade 12, only 52\% of the appropriate age population remain enrolled in South Africa (Weybright et al., 2017). The capabilities a person need in solving a problem be understanding of the concept (conceptual understanding), procedural fluency, strategic competence, adaptive reasoning, and productive disposition (Hendriana, Rohaeti \& Hidayat, 2017; Kilpatrick, Swafford \& Findell, 2001; Runisah, Herman \& Dahlan, 2017). It is why one of the capabilities that are considered important in the formation of one's mindset is mathematical reasoning ability.

The reasoning is a pattern of thinking activity in drawing a conclusion or making a new statement based on some previously known statements that are considered correct. On the other hands, educational inclusion as an educational device that breaks with exclusionary practices and spaces in the educational system and the challenges that offer to pre-service teacher's formation and also 'controversial issues' are topics under which different groups have built irreconcilable arguments on (Infante, 2010; Toledo Jofré, Magendzo Kolstrein, Gutiérrez Gianella, \& Iglesias Segura, 2015). Therefore, the reasoning abilities including educational inclusion are also needed in everyday life so that everyone in everywhere can respond and analyze any problems that arise in a comprehensive, critical, objective and logical way.

The creative reasoning is a reasoning which emphasizes on a problem-solving process that includes novelty, plausible and based on mathematical foundation (Lithner, 2008; Fathurrohman, Porter \& Worthy, 2017). In South Africa, mathematics mastery is a growing concern (Kotzé, 2007). Bergqvist (2007) suggested a framework for mathematical reasoning as follows in Figure 1. What is meant by creative reasoning is a type of reasoning that finding a solution to a mathematical problem is not only conducted by imitating solution such as samples of exercise and item tests contained in the textbooks as well as considering the algorithm or the steps of a solution? 


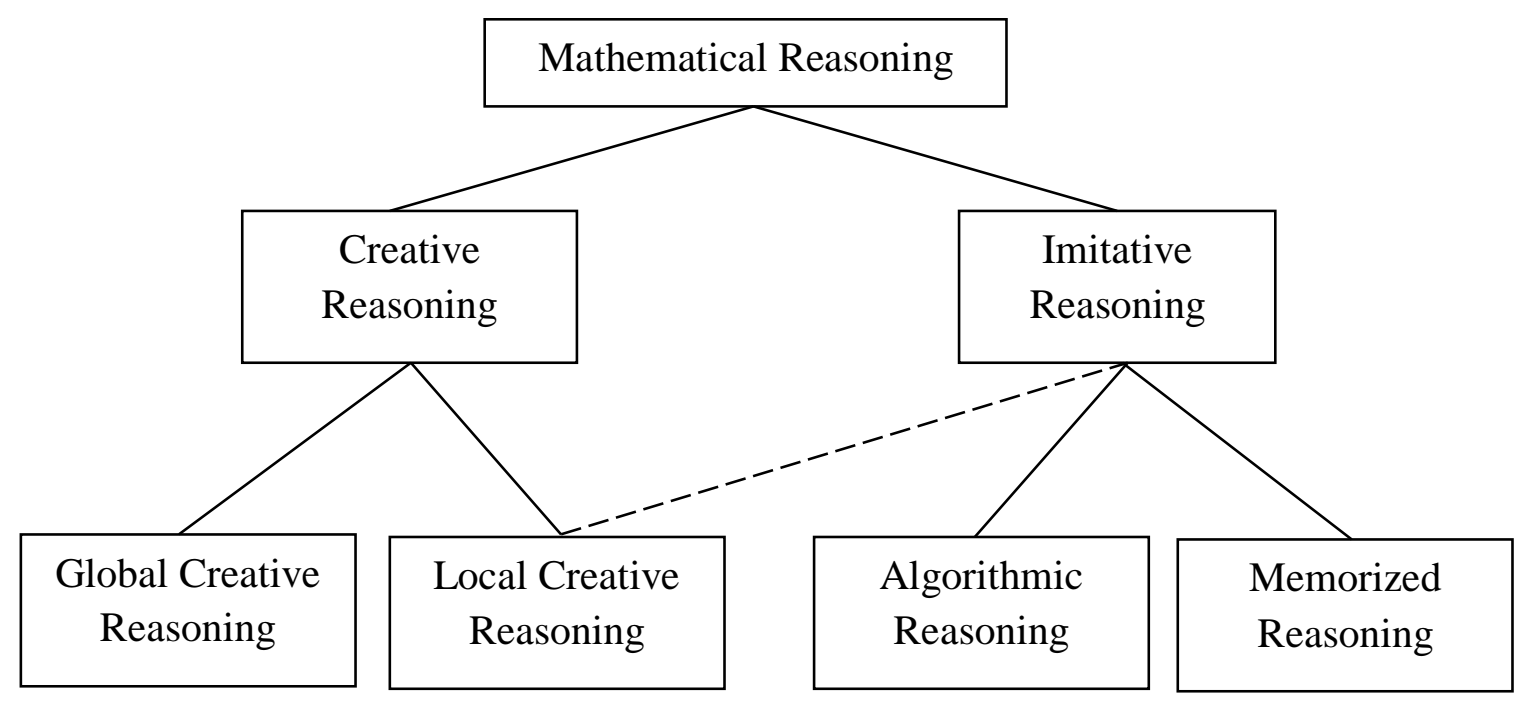

Figure 1 Framework of mathematical reasoning

The consistent attitude of a person in teaching-learning process is one determinant of success so that it can harmonize his or her attitudes and behavior to reach the expected goals (Robbins, 2010). Furthermore, Syah (2010) also stated that there are several factors determining the success of one's learning in mathematics, namely, internal \& external factors, and learning approaches. One part of students' internal factors is Adversity Quotient (AQ).

Stoltz (2004) argued that Adversity is one of the difficulties faced by someone so that there are some who have broken the spirit to face and solve the challenge. In the meantime, AQ is one's persistence in facing all obstacles to achieve success. Also, Stoltz (2004) also suggested that AQ has four key dimensions which form the basis of AQ's measuring tool. First, control is that a person's response to adversity, either slow or spontaneity. Second, origin and ownership are that the extent to which a person feels can improve the situation. Third, coverage (reach) is that the extent of the difficulties encountered in life effects. Last, endurance is that reflects how a person perceives his predicament and can persist through those difficulties. AQ is the predictor of success of a person in the face of adversity, how he behaves in a tough situation, how he controls the situation, is he able to find the correct origin of the problem, whether he takes his due ownership in that situation does he try to limit the effects of adversity and how optimistic he is that the adversity will eventually end (Phoolka \& Kaur, 2012).

AQ related to the level of a person. There are three types or levels, namely the climber (high), the camper (medium) and a quitter (low). Students who have high levels of climber would be able to overcome the difficulties faced but must still address in a way given the additional task of enrichment. In addition to the person who has a level of climber, AQ can also tap as a peer tutor to his friends who have a camper and quitter AQ level.

\section{METHOD}

The purpose of this study is to determine and analyze in depth about the mathematics teachercandidate students' mathematical creative reasoning abilities based on the level of Adversity Quotient (AQ). This study uses a mixed method of the following type by combining quantitative and qualitative methods in order. The first stage of this research, a quantitative method, is conducted to obtain measurable data. The second phase, a qualitative method, is 
carried out to explore the findings obtained from the first stage (Prahmana et al., 2017). The materials used are linear Inequality and absolute value. From the data analysis, it will result in the creative mathematical reasoning skill of the students related to Adversity Quotient level namely the climber (high), the camper (medium) and a quitter (low). The research population in this study was all students attending the course of Calculus in Mathematics Education of Graduate Study Program STKIP Siliwangi in the academic year of 2016/2017. The total members of the population consist of 270 students divided into six classes. Clusters random sampling uses to determine the experimental class as a sample. Of the six available classes, one class, A2, is selected to be the experimental one.

The results of measurements of creative mathematical reasoning skill and the categorization of Adversity Quotient, both are combined to determine subject that meets the predefined categories. The data analysis was done based on topics which fit the category. Besides, we further conducted interview towards students selected as a representative of each level in the process of creative mathematical reasoning skill. It is done to delve into some of the constraints associated with delve and their Adversity Quotient categories respectively.

\section{RESULTS AND DISCUSSION}

The findings regarding creative mathematical reasoning skills of students reviewed by the Adversity Quotient (AQ) presented in Table 1.

Table 1. Students' mathematical creative reasoning ability based on AQ

\begin{tabular}{cccc}
\hline Type of Adversity Quotient & Mean & SD & N \\
\hline Climber & $6,204(62.04 \%)$ & 1,111 & 9 \\
Champer & $6,111(61.11 \%)$ & 0,894 & 12 \\
Quitter & $4,815(48.15 \%)$ & 0,694 & 9 \\
Total & $5,750(57.50 \%)$ & 1,080 & 30 \\
\hline
\end{tabular}

Notes: Ideal Score: 10

Based on the description in Table 1, the interpretation obtained is that the development of students' mathematical creative reasoning skills, both overall or by type of Adversity Quotient (AQ) at the type of Climber and Champer, fall into the category of the medium. However, for the type of Adversity Quotient (AQ) at the Quitter types, it falls into the category of low.

Regarding supporting the description of students' mathematical creative reasoning skills that describe in Table 1, it is necessary to analyze data regarding students' mathematical creative reasoning skills through the mean test. After testing the normality of the data distribution of students' mathematical creative reasoning skills, it finds that the data normally distribute. Based on these findings, One-Way ANOVA uses to calculate the mean test of the ability above (Table 2). 
Table 2. The summary of One-Way ANOVA test of students' mathematical creative reasoning ability based on the type of AQ

\begin{tabular}{lccccc}
\hline \multicolumn{1}{c}{ Source } & JK & dk & RJK & F value & Sig \\
\hline Adversity Quotient (AQ) & 11.271 & 2 & 5.635 & 6.754 & 0.004 \\
Inter & 22.527 & 27 & 0.834 & & \\
\hline
\end{tabular}

It appears that the significance level of 5\%. The Adversity Quotient (AQ) has a significant influence towards the achievement of students' mathematical creative reasoning skills (Table 2 ). The skill is evident from the value of obtained Sig which is 0.004. So, to see which type of AQ is significantly different, then the Post Hoc Test is conducted through Scheffe test, presented in Table 3 .

Table 3. Scheffe test of the achievement of students' mathematical creative reasoning ability based on the type of AQ

\begin{tabular}{cccccc}
\hline Type of AQ $(\mathbf{I})$ & Type of AQ & $(\mathbf{J})$ & $\begin{array}{c}\text { Mean Difference } \\
(\mathbf{I}-\mathbf{J})\end{array}$ & Sig & Interpretation \\
\hline Climber & Champer & 0.0925 & 0.974 & Not different \\
Champer & Quitter & $1.2953^{*}$ & 0.013 & Different \\
Climber & Quitter & $1.3878^{*}$ & 0.012 & Different \\
\hline
\end{tabular}

Based on Table 3, it concluded that at a significance level of 5\%. There are significant differences between the students' mathematical creative reasoning ability at the type of AQ Climber \& Quitter with Champer with Quitter compared to AQ type of Climber and Champer. The implication is that the students' mathematical creative reasoning skills at AQ type of Quitter have developed more than AQ at the type of Climber and Champer. The achievement of the students' mathematical creative reasoning skills based on the indicators of novelty, plausible, and mathematical foundation presented in Table 4.

Table 4. The indicators achievement of the students' mathematical creative reasoning ability based on AQ

\begin{tabular}{cccc}
\hline \multirow{2}{*}{ Item Number } & \multicolumn{3}{c}{ Indicators of Mathematical Creative Reasoning } \\
\cline { 2 - 4 } & Mathematical Foundation & Plausible & Novelty \\
\hline Climber & $30.56 \%$ & $52.78 \%$ & $16.67 \%$ \\
Champer & $27.08 \%$ & $62.50 \%$ & $10.42 \%$ \\
Quitter & $58.33 \%$ & $38.89 \%$ & $2.78 \%$ \\
Total & $37.50 \%$ & $52.50 \%$ & $10.00 \%$ \\
\hline
\end{tabular}

Overall, the achievement of students' mathematical creative reasoning ability that includes novelty (the ability of plausible and mathematical foundation) is still low. It can be seen from the percentage of achieved novelty indicator that reached $10 \%$. While the plausible indicators (including mathematical foundation capabilities) reached $52.50 \%$ and ability that only 
includes the mathematical foundation reached $37.50 \%$. It shows that there is still some students $(37 \%)$ who solved problems based on mathematical foundation but cannot provide a reasonable excuse which has novelty.

Similarly, based on the overall, the students' mathematical creative reasoning skills students based on the type of Adversity Quotient (AQ) Climber and Champer are still likely high at the ability of Plausible (which also includes the ability of mathematical foundation) which for the climber is $52.78 \%$ and for Champer is 62.50 . As for the ability of novelty (which includes the ability of plausible and mathematical foundation), it is still significantly less compared to those who only have the ability mathematical foundation.

In contrast to the type of quitter at the type of Adversity Quotient (AQ), which indicates that the ability of only mathematical foundation (of 58.33\%) is higher than plausible capability (which also includes the ability of mathematical foundations) amounting to $38.89 \%$ and novelty (which also includes the ability of mathematical foundation and plausible) amounting to $2.78 \%$. It shows that students who have AG of quitter type are still having trouble in solving problems by providing a reasonable excuse which has a novelty.

It is clear that the students still have difficulties to solve the problems based on reasons that make sense (plausible) and which have a novelty. It is also evident from the problem-solving process is done by them presented in Figures 2, 3, 4, 5, 6, and 7.

Based on the description of the students' mathematical creative reasoning skills, it seems that students have a tendency to solve problems that are given only through the routine procedures (usually done by the lecturers), but it fell into the category of reasonable (plausible) and based on mathematical foundation. However, there are also some students who master mathematical creative reasoning capabilities that include novelty. It is evident from the students' answers in Figure 2.

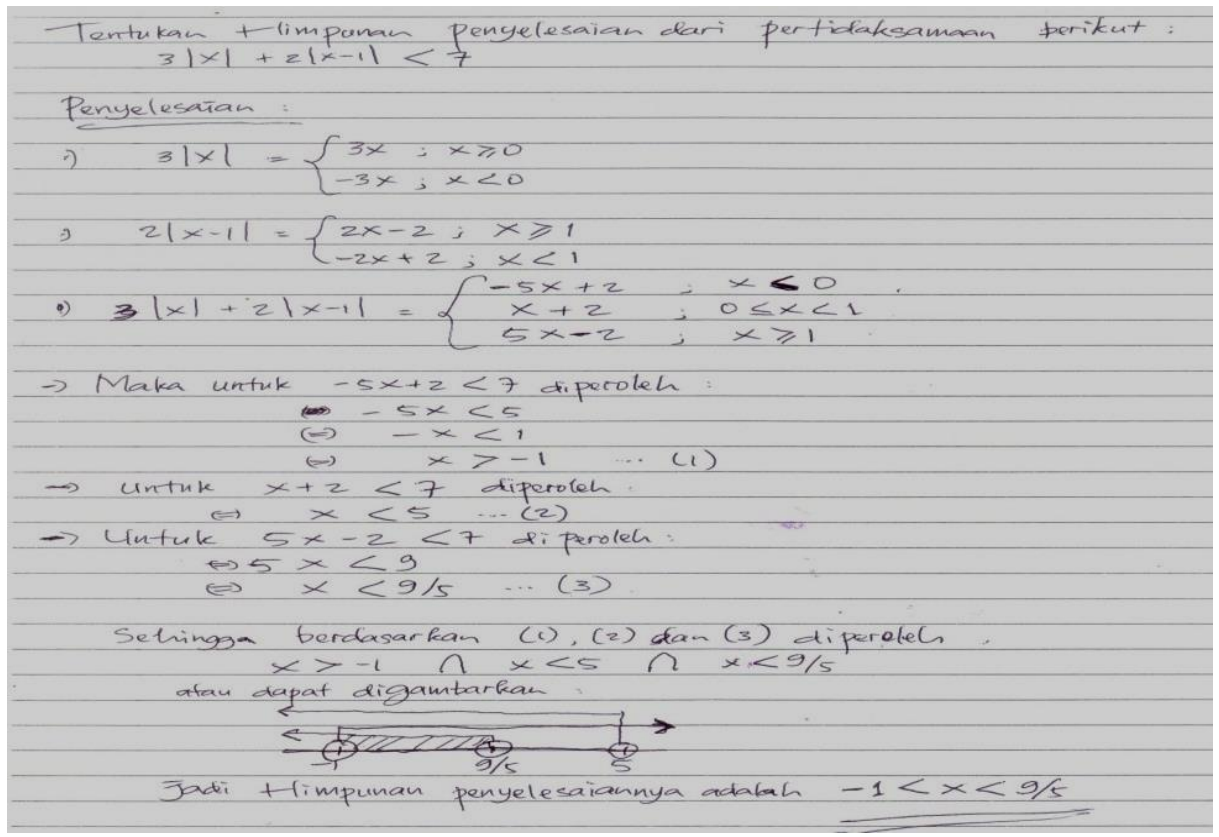

Figure 2. The results of the students' work which belong to the novelty and plausible of mathematical creative reasoning ability 
It is different from the majority of the other students' work who answered through the solving problems process in Figure 3, 4, and 5. After the interview to students regarding the results of their work conducted, the researchers conduct an interview process to gain a deeper understanding of the work that they already did. The results of the interview transcript, based on Figure 2, talk about student who has mathematical creative reasoning abilities with novelty indicator presented as follows:

Lecturer : Why did you do with a move like that?

Student 1 : I did this work with based on the definition of absolute values.

Lecturer : But if it is linked to the work of other friends who are equally based on absolute values, there is still a difference in the final settlement. What underlies your thoughts to use the concept of an incision in the inequality (1), (2) and (3) and described it on the number of the line. (Shown in Figure 2).

Student 1 : It is based on intuition, and I assume that just because the problems are about the inequality, then I think to describe it on the number of lines and an incision in the inequality (1), (2) and (3). However, although I do the work intuitively, I feel that the answers I give are reasonable and correct.

Based on interviews conducted by the student 1 , it can be concluded that the creative reasoning which falls into the category of novelty is the process of problem-solving activity done by a person which he or she thought to be a new thing.

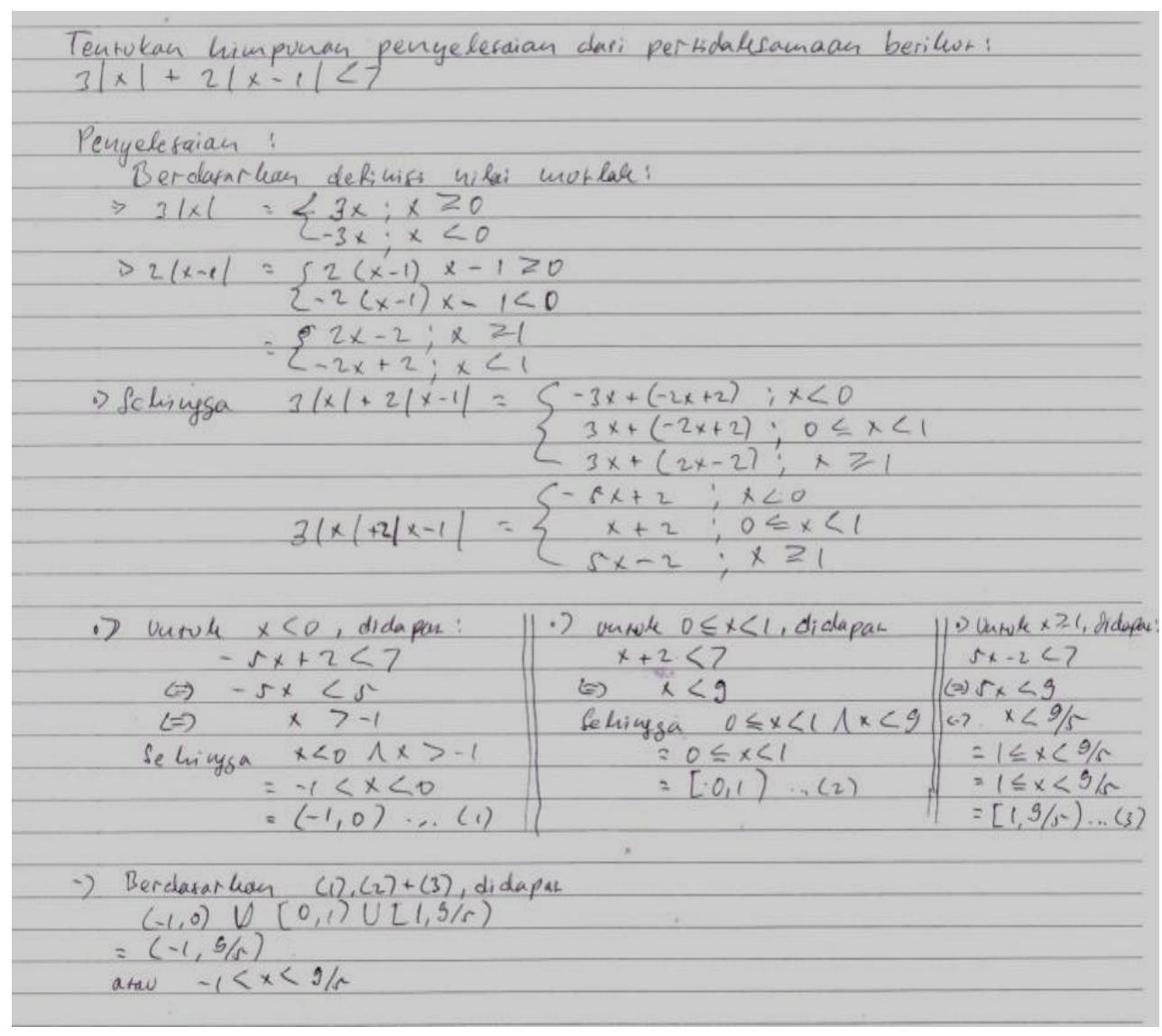

Figure 3. Results of student work which are classified as plausible on creative reasoning ability

The results of the interview transcript, based on Figure 3, talk about student who has mathematical creative reasoning abilities with plausible indicator presented as follows: 
Lecturer : do you believe that you are doing it right?

Student 2 : I believe that what I am doing is correct.

Lecturer : what underlies that the work you are doing is correct?

Student 2 : I based on the process and steps were taken by the steps on the definition of absolute value, but when connecting its inequality, I associate the limits stated in absolute value with its inequality. For example, I associate $-5 x+2$ to limit $x<0$ the inequality " $<7 "$ so $-5 x+2<7$. Then, it produced $x>-1$ and after that, I looked at the cut between $\mathrm{x}<0$ and $\mathrm{x}>-1$. So, it was obtained $-1<\mathrm{x}<0$. I did that on the boundary $0 \leq \mathrm{x}<1$ and $\mathrm{x} \geq 1$. Moreover, in the end, I made a combination of all limitations that met the value of $x$ and produced the answers $-1<x<9 / 5$.

Lecturer : why did you base on such a step?

Student 2 : I did that by discussions in groups, and the form of such items has once ever been described by my former high school teacher who taught inequalities in absolute values.

Lecturer : is the solving process of such problems a new thing to you?

Student 2 : it is not a new thing, but I have to make modifications in the process and procedure completion.

Based on interviews conducted by the student 2, it can be concluded that the creative reasoning which falls into the category of plausible is the process of problem-solving activity done by a person that he or she thought is reasonable in the process of solving it but it is not routine work. Also, a problem-solving process conducted can be done procedurally through the concepts that he or she has in mind using any possible modification.

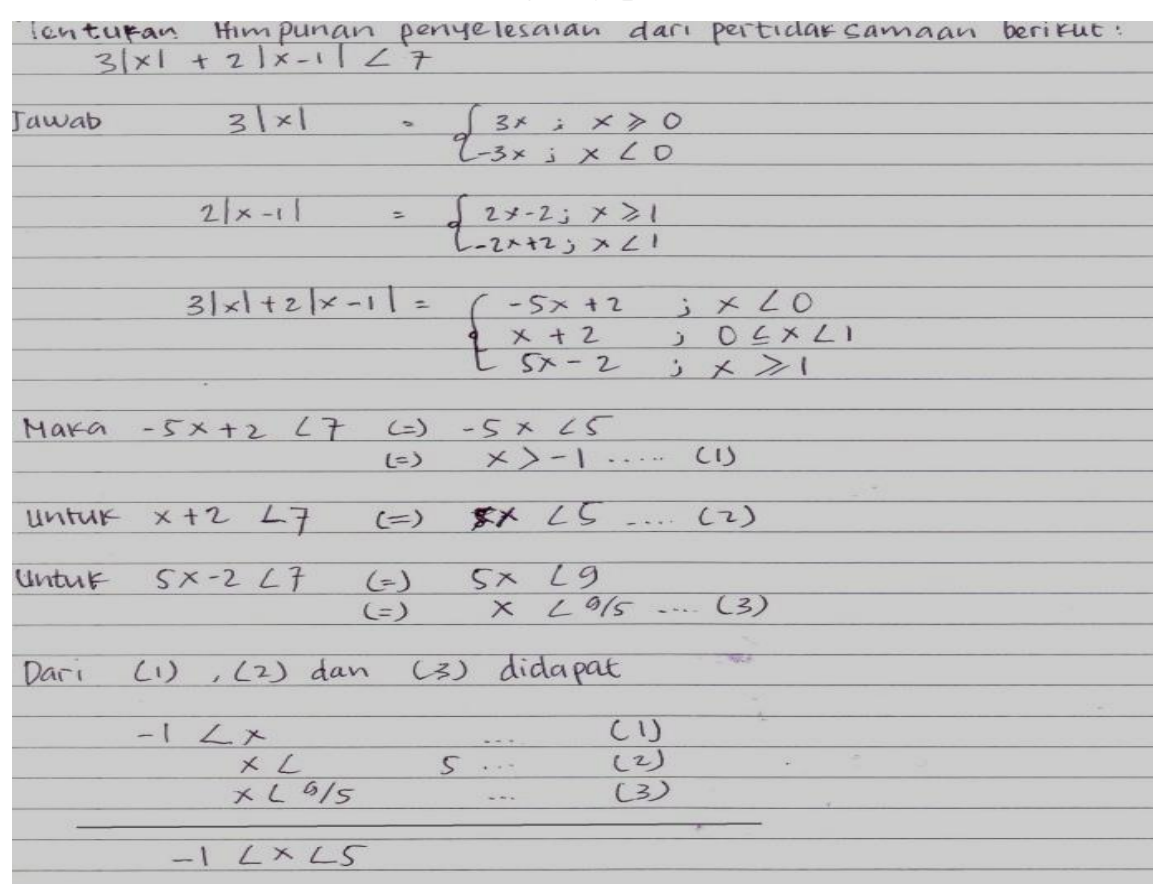

Figure 4. Result of student work classified as novelty but it has errors on the answers given

The results of the interview transcript, based on Figure 4, talk about student who has mathematical creative reasoning abilities with novelty indicators but there are some errors in the final settlement presented as follows:

Lecturer : do you believe that you are doing it right? 
Student 3 : I believe that I am doing is correct.

Lecturer : what makes you so sure that you are doing it correctly?

Student 3 : on the problems you gave to me, it was previously assumed that my answers were considered correct. The solving process of these problems is as follows in Figure 5.

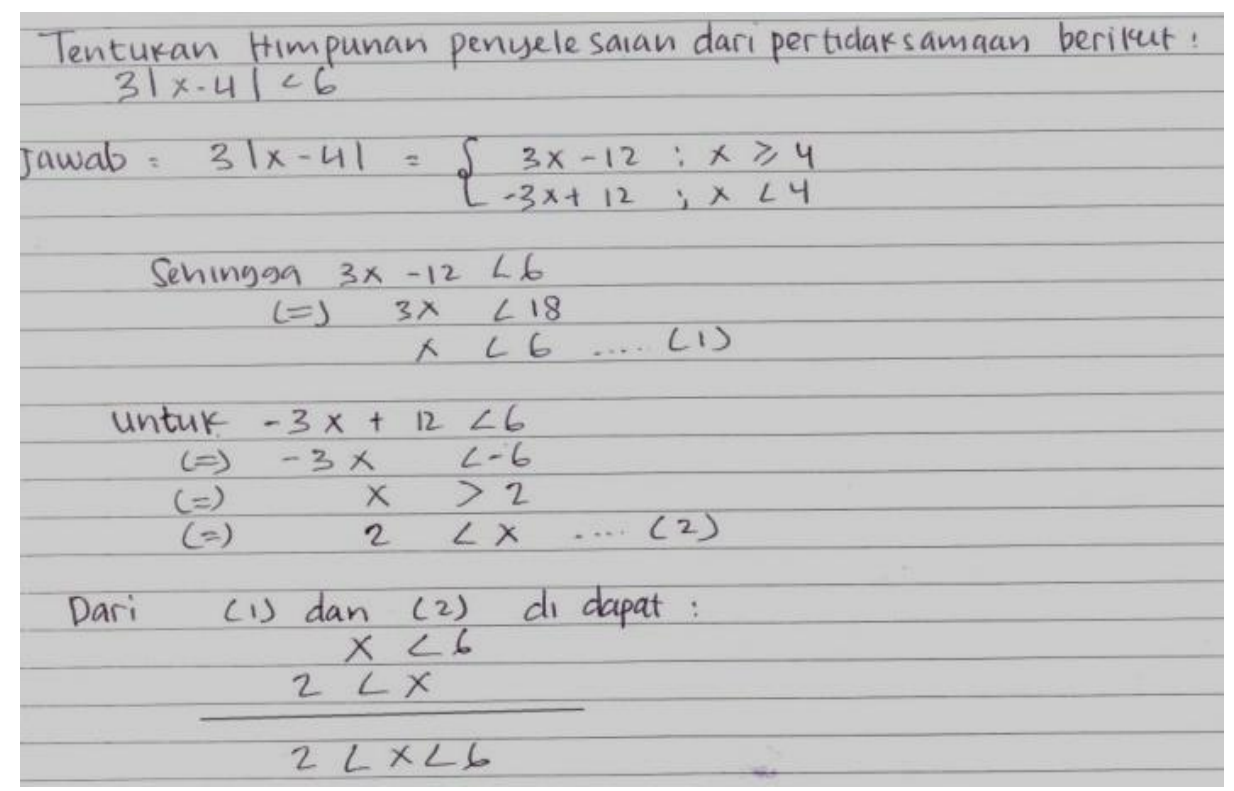

Figure 5. Results of student work on previous problems

Lecturer : Why did you do such steps, so that the final settlement is like that?

Student 3 : on the final settlement I assume that the inequality (1) and (2) meets the same $x$ value, namely, the first $x$ value is $x<6$ and the second value of $x>2$. Thus the definition is based on the absolute value:

$|\mathrm{X}|=\mathrm{X}, \mathrm{x} \geq 0$ (for which meets the positive $\mathrm{x}$ value), and

$|\mathrm{X}|=-\mathrm{x}, \mathrm{x}<0$ (for which meets the negative value of $\mathrm{x}$ ).

So I conclude that: $2<\mathrm{x}=\mathrm{x}<62 \int<\mathrm{x}<6$.

Lecturer : can the solving process on the problem of $3|x-4|<6$ that you did be applied to the problem of $3|x|+2|x-1|<7$ ?

Student 3 : I think it could be applied, Sir.

Lecturer : have you rechecked the answers that you produced?

Student 3 : I did not check it, Sir.

Lecturer : try to check the results of the answer to the problem of $3|x|+2|x-1|<7$ ?

Then, the student 3 examines the results of the answer, and the obtained results are in the following Figure 6. 


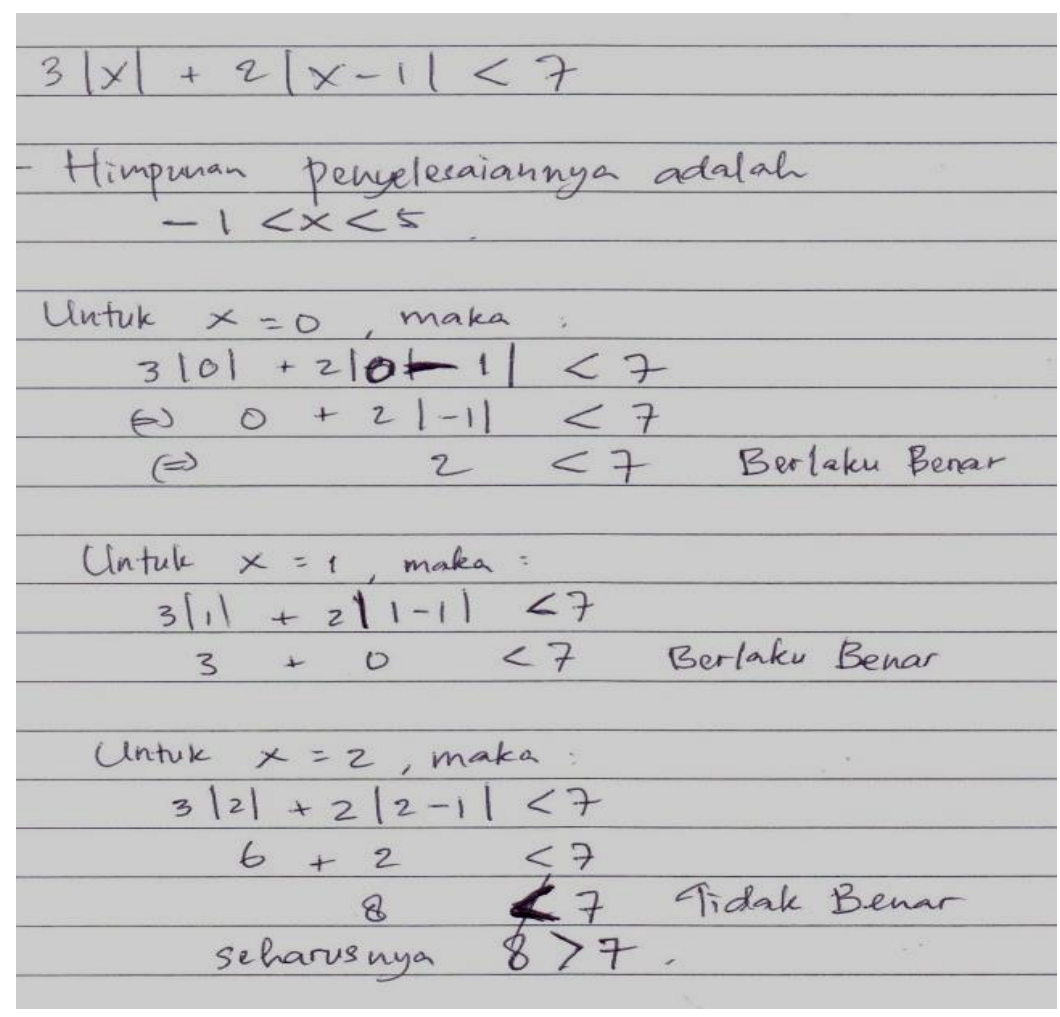

Figure 6. Results of the Recheck on students' answers

Lecturer : how is the result of the answers recheck that you produced on the problem $3|x|+$ $2|\mathrm{x}-1|<7$ ?

Student 3 : it turns out that for $\mathrm{x}=2$ does not meet the inequality of $3|\mathrm{x}|+2|\mathrm{x}-1|<7$. So, I admit that my answer was incorrect.

Based on interviews conducted by the student 3, it can be concluded that the correctness of creative reasoning on the category of novelty and plausible needs reviewing. So, the foundation of creative reasoning ability is the truth of the conclusions obtained, although the conclusion is obtained from the mathematical foundation, plausible and novelty.

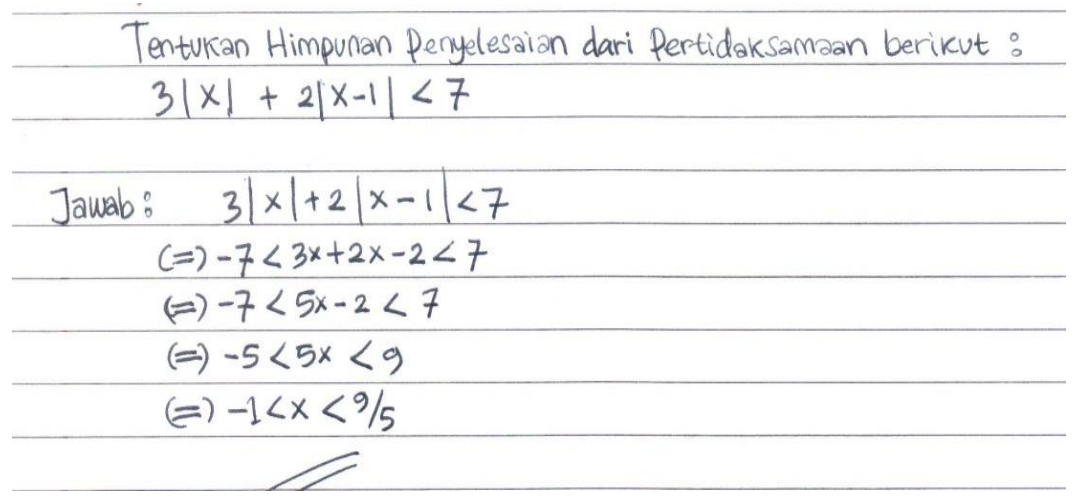

Figure 7. Results of student work categorized only on mathematical foundation in creative reasoning ability

The results of the interview transcript, based on Figure 7, talk about student who has reasoning abilities but do not belong to the creative mathematical reasoning presented as follows. 
Lecturer : are you convinced of the correctness of completion that you produced?

Student 4 : I believe that the answer I give is correct.

Lecturer : what is the basis for your belief that the answer you gave is correct?

Student 4 : what underlies me is that the work I did is by the settlement algorithms contained in textbooks.

Based on interviews conducted by students 4 , it can be concluded that he does not have a creative reasoning ability yet; he only has imitative reasoning ability. It is in line with Lithner (2008) who found that imitative reasoning is a reasoning process where someone goes through the stages of memorizing or follows an algorithmic process which is based on textbooks.

The research results show that the students can make the process of reasoning quite well. It is evident from the completion process by the students containing logical statements which can defend the truth of the results of the settlement. Ponte, Pereira and Henriques (2012) support the result that state who argued that mathematical reasoning is a process to arrive at conclusions derived from solving problem process. Also, it is in line also with Velez \& Ponte (2013) who described that mathematical reasoning is a logical statement derived from the propositions of problems given and followed by formulating and testing assumptions from certain cases so that it can produce general conclusions.

If we analyze in depth, the results of research explain that the students' reasoning process still categorize as heterogeneous thinking. It seen that they resolve the problems through algorithm procedures that can be memorized routinely. The activity shows that the students' mastery of creative reasoning is still relatively weak. It is in line with the opinions of Bergqvist (2007) who also suggested that creative reasoning which includes routine procedures in the process of problem-solving is a low creative reasoning. If the students' completion procedures in solving problems are always conducted in the same way, it is feared that the completion process will be classified into imitative reasoning abilities. The results supported by Lithner (2008) that state who found that imitative reasoning consists of memorized and algorithms reasoning. Memorized and algorithm reasoning look no different because the procedures done by the students in performing problem-solving strategies looks the same (Figueroa \& Aillon, 2015; Hidayat \& Prabawanto, 2018; Lithner, 2008).

The results of the study on students' mathematical creative reasoning skills based on grouping of AQ show that students with AQ type Quitter often encounter difficulties and easily give up in solving the problems given; in contrast with students with AQ Camper, and Climber. It supported by Phoolka \& Kaur (2012) who argued that the AQ be a supporting factor for someone to reach success of a person in dealing with difficulties; how he or she behaves in difficult situations, how he or she can control the situation, how he or she is able to find quite well the basic appearance of a problem, whether or not he or she can take a role in resolving the problems on that conditions and situation, and whether or not he or she can deal with the difficulties and how he or she can remain optimistic and confident that the difficulties will end. Also, Parvathy \& Praseeda (2014) also suggested that a person who has good AQ will be able to survive in facing difficulties in learning mathematics.

\section{CONCLUSION}

The Adversity Quotient (AQ) gives effect to the achievement of the students' mathematical creative reasoning abilities based on the overall type of Adversity Quotient (AQ), namely 
climber, champer and quitter. The achievement of the students' mathematical creative reasoning skills based on the overall and type of Adversity Quotient (AQ) of champer climber type falls into the category of the medium, while the quitter type falls into the category of low. The achievement of the students' mathematical creative reasoning skills, on indicators of novelty (which also includes the ability of plausible and mathematical foundation), has not been achieved quite well. It makes the urgency of the problems that can be solved through some efforts in the form of innovative learning which can result in a meaningful learning activity. Finally, it is highly expected that the innovative learning can improve students' Adversity Quotient so that it directly gives a good effect on students' mathematical creative reasoning skills.

\section{REFERENCES}

Acuña Ruz F. (2015). Incentivos al trabajo profesional docente y su relación con las políticas de evaluación e incentivo económico individual. Estudios pedagógicos (Valdivia), 4l(1), 7-26.

Bergqvist, E. (2007). Types of reasoning required in university exams in mathematics. The Journal of Mathematical Behavior, 26(4), 348-370.

Fathurrohman, M., Porter, A., \& Worthy, A. L. (2017). Teachers'real and perceived of ICTs supported-situation for mathematics teaching and learning. International Journal on Emerging Mathematics Education, 1(1), 11-24.

Figueroa, B., \& Aillon, M. (2015). Escritura académica de un ensayo mediado por el aprendizaje colaborativo virtual. Estudios pedagógicos (Valdivia), 41(1), 79-91.

Hendriana, H., Rohaeti, E. E., \& Hidayat, W. (2017). Metaphorical thinking learning and junior high school teachers' mathematical questioning ability. Journal on Mathematics Education, 8(1), 55-64.

Hendriana, H., Hidayat, W., \& Ristiana, M. G. (2018). Student teachers' mathematical questioning and courage in metaphorical thinking learning. In Journal of Physics: Conference Series, 948(1), 012019.

Hidayat, W., \& Prabawanto, S. (2018). Improving students' creative mathematical reasoning ability students through adversity quotient and argument driven inquiry learning. In Journal of Physics: Conference Series, 948(1), 012005.

Infante, M. (2010). Desafíos a la formación docente: Inclusión educativa. Estudios pedagógicos (Valdivia), 36(1), 287-297.

Kilpatrick, J., Swafford, J., \& Findell, B. (2001). Adding it up: Helping children learn mathematics. Washington, DC: National Academy Press.

Kotzé, G. (2007). Investigating shape and space in mathematics: A case study. South African Journal of Education, 27(1), 19-35.

Lithner, J. (2008). A research framework for creative and imitative reasoning. Educational Studies in Mathematics, 67(3), 255-276.

Parvathy, U., \& Praseeda, M. (2014). Relation between Adversity Quotient and Academic Problem among student teachers. Journal of Humanities and Social Science, 19(11), 23-26.

Phoolka, S., \& Kaur, N. (2012). Adversity Quotient: A new paradigm to explore. Contemporary Business Studies, 3(4), 67-78. 
Ponte, J. P., Pereira, M. J., \& Henriques, A. (2012). O raciocínio matemático nos alunos do ensino básico e do ensino superior. Praxis Educativa, 7(2), 355-377.

Prahmana, R. C. I., \& Kusumah, Y. S. (2016). The Hypothetical Learning Trajectory on Research in Mathematics Education using Research-Based Learning. Pedagogika, $123(3), 42-54$.

Prahmana, R. C. I., Kusumah, Y. S., \& Darhim (2017). Didactic Trajectory of Research in Mathematics Education Using Research-Based Learning. Proceeding of the Asian Mathematical Conference 2016. Bali: Indonesian Mathematical Society.

Robbins, S. P. (2010). Manajemen. Jakarta: Erlangga.

Runisah., Herman, T., \& Dahlan, J. A. (2017). Using the 5E learning cycle with metacognitive technique to enhance students'mathematical critical thinking skills. International Journal on Emerging Mathematics Education, 1(1), 87-98.

Soedjadi, R. (2000). Kiat pendidikan matematika di Indonesia. Jakarta: Direktorat Jenderal Pendidikan Tinggi Departemen Pendidikan Nasional.

Stoltz, P. G. (2004). Adversity Quotient: Mengubah hambatan menjadi peluang. Jakarta: Grasindo.

Syah, M. (2010). Psikologi belajar. Jakarta: Rajagrafindo Persada.

Toledo Jofré, M,, Magendzo Kolstrein, A., Gutiérrez Gianella, V., \& Iglesias Segura, R. (2015). Enseñanza de'temas controversiales' en la asignatura de historia y ciencias sociales desde la perspectiva de los profesores. Estudios pedagógicos (Valdivia), 41(1), 275-292.

Velez, I., \& Ponte, J. P. D. A. (2013). Representations and reasoning strategies of Grade 3 students in problem solving. In B Ubuz, C Haser \& MA Marioti (eds). Proceedings of the Eight Congress of the European Society for Research in Mathematics Education. Ankara: Middle East Technical University.

Visser, M., Juan, A., \& Feza, N. (2015). Home and school resources as predictors of mathematics performance in South Africa. South African Journal of Education, 35(1), $1-10$.

Weybright, E. H., Caldwell, L. L., Xie, H., Wegner, L., \& Smith, E. A. (2017). Predicting secondary school dropout among South African adolescents: A survival analysis approach. South African Journal of Education, 37(2), 1-11.

Young, J. R. (2017). Technology integration in mathematics education: Examining the quality of meta-analytic research. International Journal on Emerging Mathematics Education, $1(1), 71-86$. 
96 Hendriana, Prahmana, \& Hidayat, Students' Performance Skills in Creative ... 